\title{
Cortinarius testaceofolius sp. nova, a common Telamonia of the taiga
}

\author{
HÅKAN LINDSTRÖM \& KARL SOOP
}

\begin{abstract}
LINDSTRÖM H. \& SOOP K.: Cortinarius testaceofolius sp,. nova, a common Telamonia of the taiga.- Karstenia 35:91-95 Helsinki. ISSN 0453-3402

Cortinarius testaceofolius H.Lindstr. \& Soop, sp. nova is described from Sweden and Norway. The species is characterised principally by its conspicuous brick-red gills, and is associated with Picea abies, more rarely with Pinus sylvestris. It seems to be one of the most common members of subgen. Telamonia in oligotrophic spruce forests of the northern taiga region.
\end{abstract}

Key words: Agaricales, Cortinarius, Telamonia, Picea, mycorrhiza

Håkan Lindström, Östansjö 2357, S-84 064 Kälarne, Sweden

Karl Soop, Elinshillsv. 9, S-13248 Saltsjö-Boo, Sweden

\section{Introduction}

Cortinarius is one of the dominant mycorrhizal geni in the vast forests of Northern Fennoscandia, and Telamonia is without doubt its dominant subgenus, in terms of both fruiting and number of species. The region is far from explored (Soop 1993), and new species of fungi, many of them Cortinarii, are discovered and described every year. Nevertheless it is surprising that the present taxon has apparently not been formally described (it was briefly introduced as an unpublished variety of C. tortuosus (Fr.:Fr.)Fr. in Soop 1994). It appears to be one of the commonest middle-sized Telamonice of spruce forests in the region, and while it may be easily overlooked on superficial examination in the field, it is not difficult to characterise.

Cortinarius testaceofolius H.Lindstr. \& Soop, sp. nova - Figs. 1-3

C. tortuosus (Fr.:Fr.)Fr. var. insignis Soop, Jordstjärnan 15, 1994, nom. inval.
Illustrations: Soop (1994, inside cover; as C. tortuosus var. insignis).

Pileo 3-6(9) cm, conico, deinde convexocampanulato, parum carnoso; lævis, ex glabro minute innato fibrilloso, hygrophano; primo griseomicaceo, fulvo-testaceo, margine pallidior. Lamellis saturate testaceis, deinde fulvo-badiis; subconfertis; acie pallidior. Stipite $6-15 \times 0.4-$ $1.2 \mathrm{~cm}$, equale vel leviter clavato, interdum radicante; albocanscente, deinde pallide testaceo. Velo cortinaque albis, fugaceis. Carne pallide fusco-fulva, odore saporeque nullis. Sp. ellipsoideis, $8-9 \times 5-6 \mu \mathrm{m}$. React. carne ope $\mathrm{NaOH}$ vix ulla. In piceetis.

Type: Sweden. Ångermanland: Säbro parish, Furuhultsån, 23.VIII.1987 CPF583 (S, holotype).

Cap 3-6(9) cm; young campanulate to cone shaped, soon expanding, later plano-convex, usually distinctly umbonate, when old often upturned. Cutis smooth, minutely innate fibrillose, mat to somewhat oily shining, dry to slightly viscid in moist weather, somewhat translucently striate at margin; hygrophanous, often with a characteristic 


\section{$5 \mathrm{~cm}$}
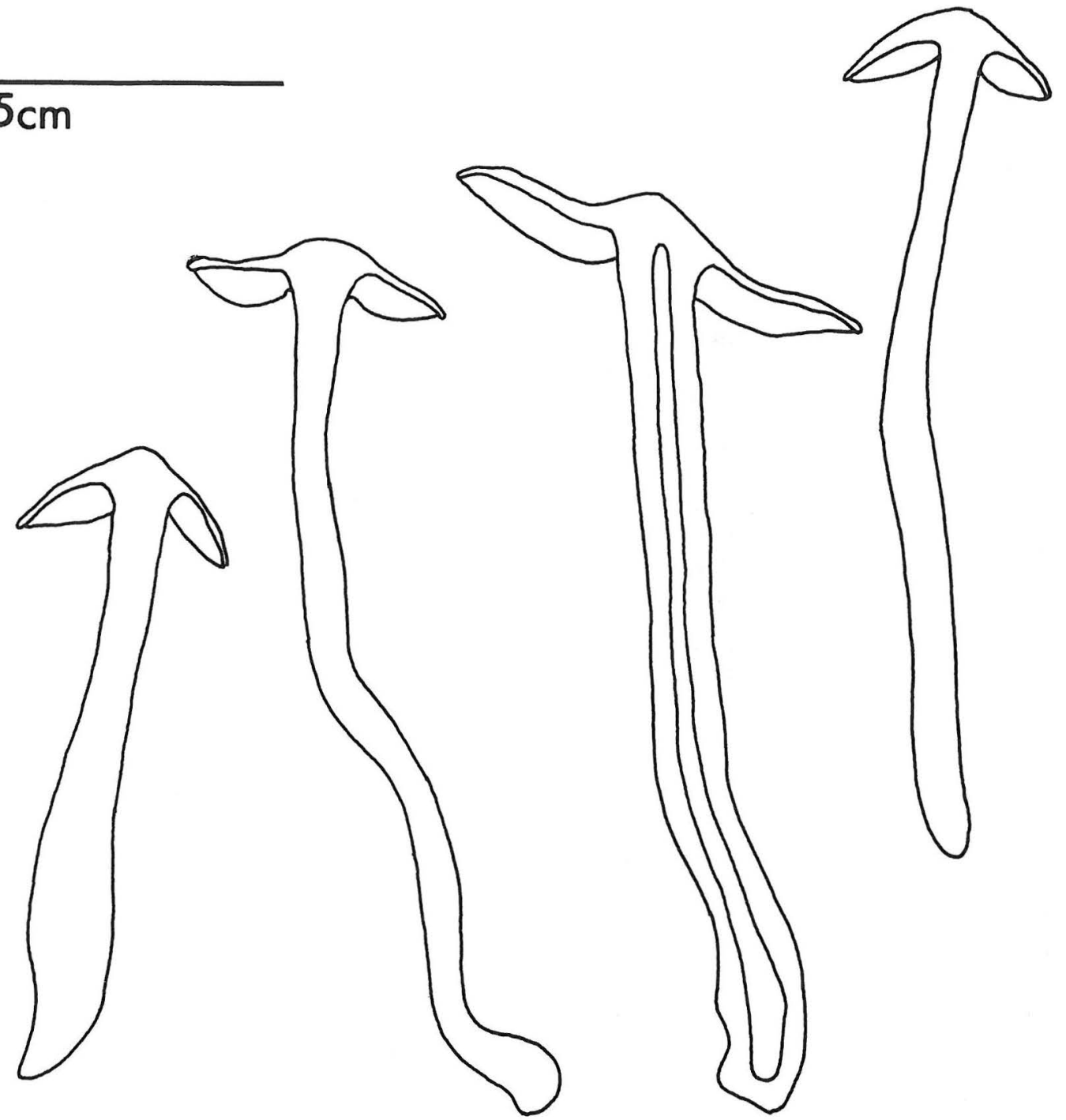

Fig. 1. C. testaceofolius H.Lindstr. \& Soop, habit sketch (HL92.103)

concentric updrying zone, saturated red brown to dark apricot (Caill. S35, S39, S37), margin somewhat paler and more yellowish (R37, P20), drying dull orange brownish, young greyish micaceous; margin with sparse white fibrils.
Gills moderately crowded to crowded $(\mathrm{L}=$ $40-60,1=2-3$ ), emarginate to adnexed; broad; saturated brick red to (yellowish) red brown (Caill. R37, R 39), when older often dark spotted; edge sometimes paler and uneven. 


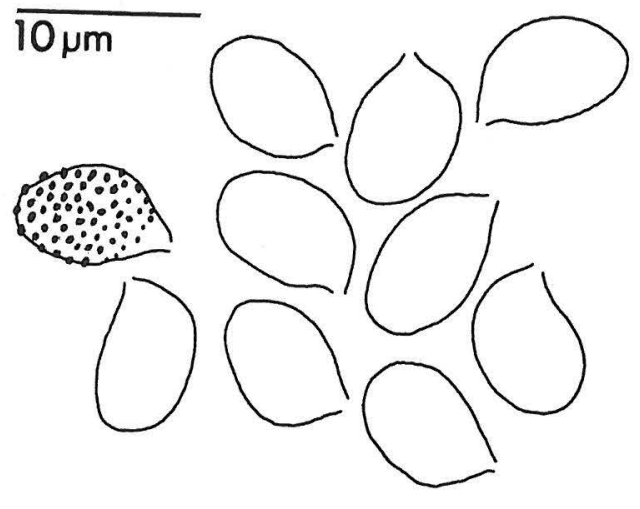

Fig. 2. Spores of C. testaceofolius H.Lindstr. \& Soop (HL87.199)

Stipe long and slender, 6-15(20) $\times 0.4-$ $1.2(1.5) \mathrm{cm}$, cylindrical to slightly claviform with expanded base $(<2 \mathrm{~cm})$, often radicant reaching deeply into the humus, sometimes tortuous; minutely fibrillose; young white, somewhat shiny with greyish hygrophanous stripes, gradually ochraceous to pale brick or grey brown. Veil white, thin, forming sparse girdles or irregular zones, later fibrillose, indistinct. Cortina fugaceous, white.

Flesh soft, somewhat cartilaginous in stipe cortex, sometimes hollow at the centre; red brown in cap, in stipe contrasting pale grey to ochraceous brown, sometimes with a pink flush or faintly marbled tan. Smell and taste insignificant. Reaction with $\mathrm{NaOH}$ trivial (vaguely brownish to grey) in flesh and on cutis and gills; guajac nil.

Spores (7.5)8-9(10) × (4.5)5-6(6.5) $\mu \mathrm{m}$, broadly elliptic, weakly to moderately verrucose, more distinctly so near apiculus (Fig. 2). Gill edge fertile with 4-spored basidia and scattered, commensurate, clavate sterile cells. Cap cuticle (Fig. 3) with moderately thin epicutis (5-9 layers); hyphæ in upper part often separated, 2-4(7) $\times 50$ $100 \mu \mathrm{m}$, hyaline; in lower part more regular and gradually wider $(4-7 \mu \mathrm{m})$, with faintly pigmented walls. Hypoderm of well differentiated hyphæ, 5$25 \times 40-60(110) \mu \mathrm{m}$, with brownish thick-wall pigments, in lower part also with a few narrow, granular pigmented hyphæ. Trama with more irregular hyphæ, some expanded, 5-10(20) $\mu \mathrm{m}$, some minutely pigmented.

Ecology. In boreo-nemoral to boreal and montane coniferous forests. Foremost with Picea abies, but

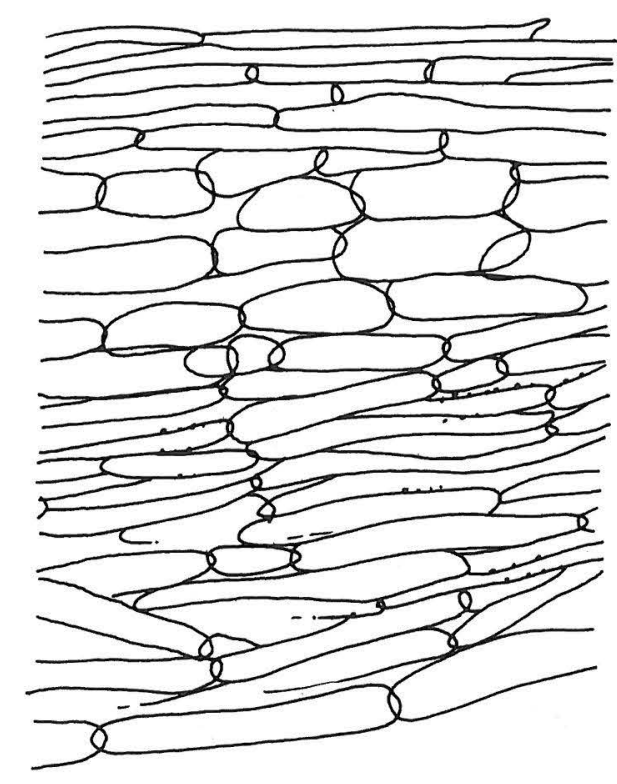

Fig. 3. Pileocutis of C. testaceofolius H.Lindstr. \& Soop (HL87.199)

also under Pinus sylvestris on oligotrophic dry to moist ground. In small groups, non-fasciculate; typically among Vaccinium shrub and in dense carpets of Pleurozium schreberi or Hylocomium splendens. Common in Northern Fennoscandia, more uncommon in the South; fruiting Aug.-Oct.

Specimens examined $(\mathrm{CPF}=$ Cortinarius Photographica Flora, in herb. S; HL = herb. Håkan Lindström; KS = herb. Karl Soop; addresses above)

Sweden. Medelpad: Borgsjö, Lillberg, 13.IX.1982 CPF55; Västmanland: Arboga, Ramstigsberget, 25.VIII,1987 KS234; Jämtland: Hällesjö S Ansjö, IX.1987 HL87.199; Jämtland: Ragunda, Kullstabodarna, VIII.1988 HL88.030; Jämtland: Rätans, Rätan, 16.VIII.1992 KS545; Uppland: Boo, Orminge, 30.VIII.1992 KS567; Jämtland: Håsjö, Kvarnån, IX.1992 HL92.103; Lycksele Lappmark: Storuman, Yttre Tjäresten, 20.VIII.1993 KS635; Dalarna: Malungs, Öjsberget, 8.IX.1994 KS673; Västmanland: Arboga, Röfors, 17.IX.1994 KS685. Norway. Oppland: Stordals, Attna, 14.IX.1983 CPF159.

\section{Discussion}

This medium-sized Telamonia is characterised by its red-brown cap, long, often radicant stipe with a thin white veil, and conspicuously saturated brick 
gills (approximately the same as found with the non-hygrophanous $C$. laniger $F r$.). We have found it to be one of the most common representative of the subgenus in acidic spruce forests with blueberry, especially in the mountainous areas of Northern Fennoscandia.

Habit and general coloration suggest C. illuminus Fr., but this species differs in paler, cinnamon gills and subglobose spores. C. armeniacus (Schff.:Fr.)Fr., while similar in many respects, differs in a duller gill hue, stouter non-radicant stipe, and slightly broader spores. Our species also resembles $C$. biformis Fr., which differs, however, in having a frequent violet tinge at the stipe apex, trivially ochre gills, and smaller spores. One of the collections (KS567) has a vaguely ochre veil, but as there is no other difference, we consider it an occasional aberration.

C. testaceofolius was first presented as a variety insignis ined. of C. tortuosus (Fr.:Fr.)Fr. (Soop, 1994). The correct rank of this taxon has been the subject of some controversy. It may appear close to C. tortuosus, from which it differs macroscopically in lacking a violet coloration on stipe and in flesh, and in presenting a generally brighter cap coloration. Microscopically the two taxa are similar, both with a hyaline epicutis and pigment relatively deep in the hypoderm. On the other hand, we have never observed any intermediate forms, and there is no doubt in our minds that they should be regarded as separate species. One may note in this context that one specimen in Fries' unpublished icon of C. tortuosus (preserved in S) is remarkably similar to our fungus in coloration, whereas Fries' diagnosis points to the typical tortuosus as it is commonly accepted by contemporary mycologists.

Our species appears well distributed in Sweden and probably grows in other parts of Europe. As it is not rare, we would expect it to have been described. In the works of Fries, C. dilutus (Pers.)Fr. comes close, but the interpretation is problematic and this name must be excluded (cf. Melot in Brandrud \& al (1992, 2:19). C. erugatus (Weinm.)Fr. and C. hoeftii (Weinm.)Fr. are also close, placed next to dilutus in Epicrisis, but Weinmann's protologues are too short and vague to be conclusive. Karsten in all probability met our species, but does not appear to have described a taxon displaying its prime characters (he may have used some name given by Fries or Weinmann).

Velenovský (1920-22, 1939) described several Hydrocybe species with vividly coloured gills, but these are almost all too small to fit our fungus. $H$. rigellice is perhaps the most likely candidate: it has lamellis....pallide igneo rubro-brunneis, it seems to match our dimensions, and the spores are ovatoellipsoideis, 7-8 $\mu \mathrm{m}$. On the other hand, it grows with Fagus, and appears somewhat darker than our species (the author compares it with C. balaustinus) with a stipe infra obscure castaneo.

Among Henry's many descriptions of new Cortinarii, we have not been able to find a valid, published name which fits our species. Reumaux (1984) describes C. tricolor, which differs in having distinctly smaller spores. The same is true for C. privignofulvus Hry ss. Reumaux \& Moënne-Loccoz (1991), which agrees in general coloration, with gills rouge-vif. (Note, however, that Henry states crême-ochré in the protologue 1948.) C. privignus Fr. ss Reumaux [op. cit.] especially as illustrated by the painting - also resembles our fungus, although the stipe is too robust and it is said to possess a distinct odour. On the other hand, this cannot be Fries' C. privignus, which is described as a rare species near C. malachius with totally different coloration, notably pileo...argenteo-canescente, lamellis...ex aquose, opacce cinnamomeis.

We therefore give this common taxon a new name, Cortinarius testaceofolius, inspired by its most characteristic feature: the vivid colour of the gills. A photo of the holotype will be published in Brandrud \& al, Cortinarius, Flora Photographica, part IV.

\section{References}

Brandrud, T.E., Lindström H., Marklund H., Melot J., Muscos S. 1989-1994: Cortinarius Flora Photographica, parts I-III, Härnösand.

Cailleux, A. 1981: Code des couleurs de sols, Boubée, Paris [abrév.: Caill.].

Fries, E. 1838: Epicrisis Systematis Mycologici, Uppsala.

Henry, R. 1948: De Cortinarius bivelus Fries à Cortinarius armeniacus Fries; quelques Cortinaires privignoïdes. — Bull. Soc. Mycol. France 64:33-49.

Reumaux, P. 1984: Etude de quelques Hydrocybes aux couleurs vives. - Bull. Soc. Mycol. France 100:83-110.

Reumaux, P \& Moënne-Loccoz, P. 1991: Atlas des Cortinaires (Pars III). —Éditions Fédération Mycologique Dauphiné-Savoie: pl. 61, fiche 112.

Soop, K. 1993: On Cortinarius in boreal pine forests. - Agarica 12(21): 101-116.

Soop, K. 1994: En ny titt på spindlingar inom gruppen 
Smör-\&-Bröd, Jordstjärnan 15(1):4-11. Velenovský, J. 1939: Novitates: 101-16.

Velenovský, J. 1920-22: České Houby, Praha.

Weinmann, J.A. 1836: Hymeno- et gasteromycetes Received on 15 May 1995 hucusque in Imperio Rossico observatos recensunt, Petropoli. 